Ann. Biol. anim. Bioch. Biophys., 1978, 18 (4), 969-975.

\title{
Precocious induction of maturation and ovulation in northern pike (Esox lucius)
}

par G. DE MONTALEMBERT, B. JALABERT, C. BRY

Laboratoire de Physiologie des Poissons, I. N. R. A., 78350 jouy en Josas, France.

Summary. The efficiency of partially purified salmon gonadotropin (PPSG) and human chorionic gonadotropin (HCG), administered alone or in association with a progestagen (17 $\alpha$-hydroxy, $20 \beta$-dihydroprogesterone : $17 \alpha-20 \beta \quad \mathrm{P}$, or $17 \alpha$-hydroxyprogesterone : $17 \alpha \mathrm{P})$ was investigated in submature females using the germinal vesicle in non-peripheral position as the criterium for initial oocyte stage. A dose of $0.1 \mathrm{mg}$ PPSG $/ \mathrm{kg}$ gave satisfactory ovulation ( 89 p. 100) and fertilization ( $83 \mathrm{p} .100$ ) rates ; a minimum dose of $0.03 \mathrm{mg} / \mathrm{kg}$ was required to induce maturation without ovulation. The same dose of PPSG $(0.03 \mathrm{mg} / \mathrm{kg})$ combined with $17 \alpha-20 \beta \mathrm{P}(3 \mathrm{mg} / \mathrm{kg})$ or $17 \alpha \mathrm{P}(3 \mathrm{mg} / \mathrm{kg}) 1$ day later led to full maturations and partial ovulations. $17 \alpha-20 \beta P(3 \mathrm{mg} / \mathrm{kg})$ administered alone caused maturation in all animals and partial ovulation or no ovulation. In all the above cases using the combined treatment or $17 \alpha-20 \beta \mathrm{P}$ alone, fertilization rates were low (20 to 41 p. 100). HCG alone or associated with $17 \alpha-20 \beta \mathrm{P}(3 \mathrm{mg} / \mathrm{kg})$ was unable to induce ovulation. It is emphasized that treatment should be started as soon as possible after capture. Three-day captivity prior to treatment led to ovarian atresia and a significant decrease in ovulation rates.

\section{Introduction.}

Hormonal control of ovulation is of particular interest in northern pike (Esox lucius) since the normal sequence of oocyte maturation and ovulation does not occur under confinement, even in submature femoles captured after the completion of vitellogenesis. Furthermore, most females quickly undergo ovarian atresia and may die after a few weeks (Portal, 1947 ; Chimits, 1947, 1956 ; De Montalembert ef al., unpublished data). Performed in one or several injections, hypophysation with carp pituitaries has been somewhat successful (Sorenson et al., 1966), but precise data on the state of maturity of recipient females, as well as the actual efficiency of the treatment (ovulation and fertilization/hatching rates), are lacking. Moreover, the females were held for several days in tanks before the treatment was started. Recent experiments in carp (Jalabert ef al., 1977) showed that the combined use of fish pituitary extracts and a steroid, $17 \alpha$-hydroxy-20 $\beta$-dihydroprogesterone $(17 \alpha-20 \beta$ P) can be more efficient in marginal temperature conditions than the classical hypophysation method which requires ten times more pituitary material. 
Consequently, the purpose of the present study was double. Firstly, we wished to assess the efficiency of various hormonal treatments (gonadotropic preparations and/or steroids) on in vivo maturation and ovulation in pike. Since another salmon gonadotropic preparation (SG-G100) was found active on in vitro maturation of northern pike oocytes (Jalabert and Breton, 1973), we used a partially purified salmon gonadotropin in the absence of homologous pituitary extracts. Human chorionic gonadotropin (HCG) was also tested; this substance is unable to induce in vitro oocyte maturation in northern pike (Jalabert and Breton, 1973) or in trout and goldfish (Jalabert et al., 1972, 1973), but may trigger in vivo ovulation in a number of fish species (see review by Shehadeh, 1975). The two steroids employed were (1) $17 \alpha$ $20 \beta \mathrm{P}$ which is the most efficient steroid found so far on in vitro maturation of northern pike oocytes (Jalabert and Breton, 1973), and (2) an inexpensive substitute, 17 $\alpha$-hydroxyprogesterone $(17 \alpha \mathrm{P})$.

We also studied the possible effect of captivity prior to treatment on the efficiency of the latter.

\section{Material and methods.}

The experiments were performed in March and April 1977. Natural ponds («Etangs des Dombes ») were emptied at various periods. Two to 3-year old northern pike breeding females weighing 0.8 to $2 \mathrm{~kg}$ were collected and kept in darkness inside floating cages in the Rhone river at a temperature of 9 to $10^{\circ} \mathrm{C}$. The hormonal treatment was started in the above conditions on these fish at different time intervals after capture. The spawners were then transported to the laboratory and again kept in darkness at a temperature of about $12{ }^{\circ} \mathrm{C}$. The fishes were anesthetized in a solution of 2-phenoxyethanol (Merck) $(0.5 \mathrm{ml} / \mathrm{l})$ before every ovarian sampling or injection.

Injected material. - The products were injected intraperitoneally and dosed in order to introduce the same volume of physiological saline $(1 \mathrm{ml} / \mathrm{kg})$ into each fish.

Partially purified salmon gonadotropin (PPSG) was prepared from salmon (Oncorhynchus tschawytscha) pituitary glands according to the method described by Idler ef al. (1975) and modified by Breton et al. (1978). This preparation was slightly more active than SG-G 100 (Donaldson ef al., 1972) on in vitro maturation of trout oocytes and 5.7 times less active than purified S-GTH (Jalabert and Breton, unpublished data). The preparation of $17 \alpha-20 \beta \mathrm{P}$ (crude preparation, 4 pregnen-17 $\alpha, 20 \beta-$ diol-3 one) has been described by Jalabert ef al. (1977). $17 \alpha P$ (4 pregnen-17 $\alpha$-ol3 one) was purchased from Roussel ; HCG (Human Chorionic Gonadotropin, « Chorillon ») was provided by Intervet.

Prior to injection, steroids were first dissolved in pure ethanol as a stock solution, then precipitated as a suspension in physiological saline just before injection (20 p. 100 ethanol in the injected products).

Defermination of oocyte stage. - Some oocytes from the females were sampled before treatment and during each experiment by gentle manual pressure. They were then put into Stockard's solution for a short time to visualize the germinal vesicle (GV) and determine the oocyte stage according to the following classification (Jalabert et al., 1976) : 
i : GV in non-peripheral position (« immature » stage),

$1: G V$ in peripheral position,

2 : Maturing oocyte (GV still visible).

3 : Matured oocyte (after GV breakdown),

4 : Matured and ovulated oocyte.

Only females with oocytes at stage $i$ were used in the experiments. In order to avoid excessive handling and after preliminary observation, females were checked for ovulation on the third day after treatment and on the next 2 days whenever necessary.

Defermination of ovulation rate. - All females were killed to check the stage of the ovarian remnants either after ovulation and egg sampling or after 8 days, if ovulation had not occurred. The sampled ova and the ovarian remnants were weighed; ovulation rate was determined as the ratio of ovulated oocyte weight to initial ovary weight (ovulated oocytes plus remnants).

Determination of fertilization rate. - Three hundred ova per female were inseminated in $10 \mathrm{ml} \mathrm{DIA}$ TG diluent (Billard, 1977) with $10 \mu \mathrm{l}$ sperm pooled from 10 males (dilution rate $: 1 / 1000$ ) and incubated in a fine mesh trough at about $12{ }^{\circ} \mathrm{C}$. The fertilization rate was determined as the percentage of embryos at 40 degree-days.

Statistical analysis. - The mean values of the ovulation and fertilization rates and their confidence limits at the 95 p. 100 level of probability were computed using the angular (arc-sine) transformation of the percentages. The levels of significance were determined by the F-test after angular transformation of the percentages.

\section{Results.}

Ovulatory response (table 1).

Four types of responses were observed depending on the nature of the treatment and the animal:

Total ovulations were clear-cut (ovulation rate : 100 p. 100). The highest dose of PPSG $(0.1 \mathrm{mg} / \mathrm{kg})$ was the only treatment able to induce such a response (6 fishes out of 14).

Partial ovulations occurred in some females after treatment with the highest dose of PPSG or after sequential treatment. With PPSG $(0.1 \mathrm{mg} / \mathrm{kg})$ the remaining oocytes were degenerating. With sequential treatment (PPSG, 0.02 to $0.03 \mathrm{mg} / \mathrm{kg}+17 \alpha-$ $20 \beta \mathrm{P}$ or $17 \alpha \mathrm{P}, 3 \mathrm{mg} / \mathrm{kg}$ ) and with $17 \alpha-20 \beta \mathrm{P}$ alone, the remaining oocytes either matured (stage 3 ) or remained at stage $i$ and started to degenerate.

Maturation of some oocyfes without ovulation : low doses of PPSG $(0.02-0.03 \mathrm{mg} / \mathrm{kg})$ and $17 \alpha-20 \beta$ P alone or associated with a priming dose of PPSG $(0.02 \mathrm{mg} / \mathrm{kg})$ induced the maturation of a number of oocytes in some fishes. Other oocytes were in stage $i$ and degeneration.

No response : with a low priming dose of PPSG $(0.02 \mathrm{mg} / \mathrm{kg})$ alone or in conjunction with $17 \alpha-20 \beta \mathrm{P}$, some of the females did not show any response; the oocytes were in stage $i$ and undergoing degeneration. 


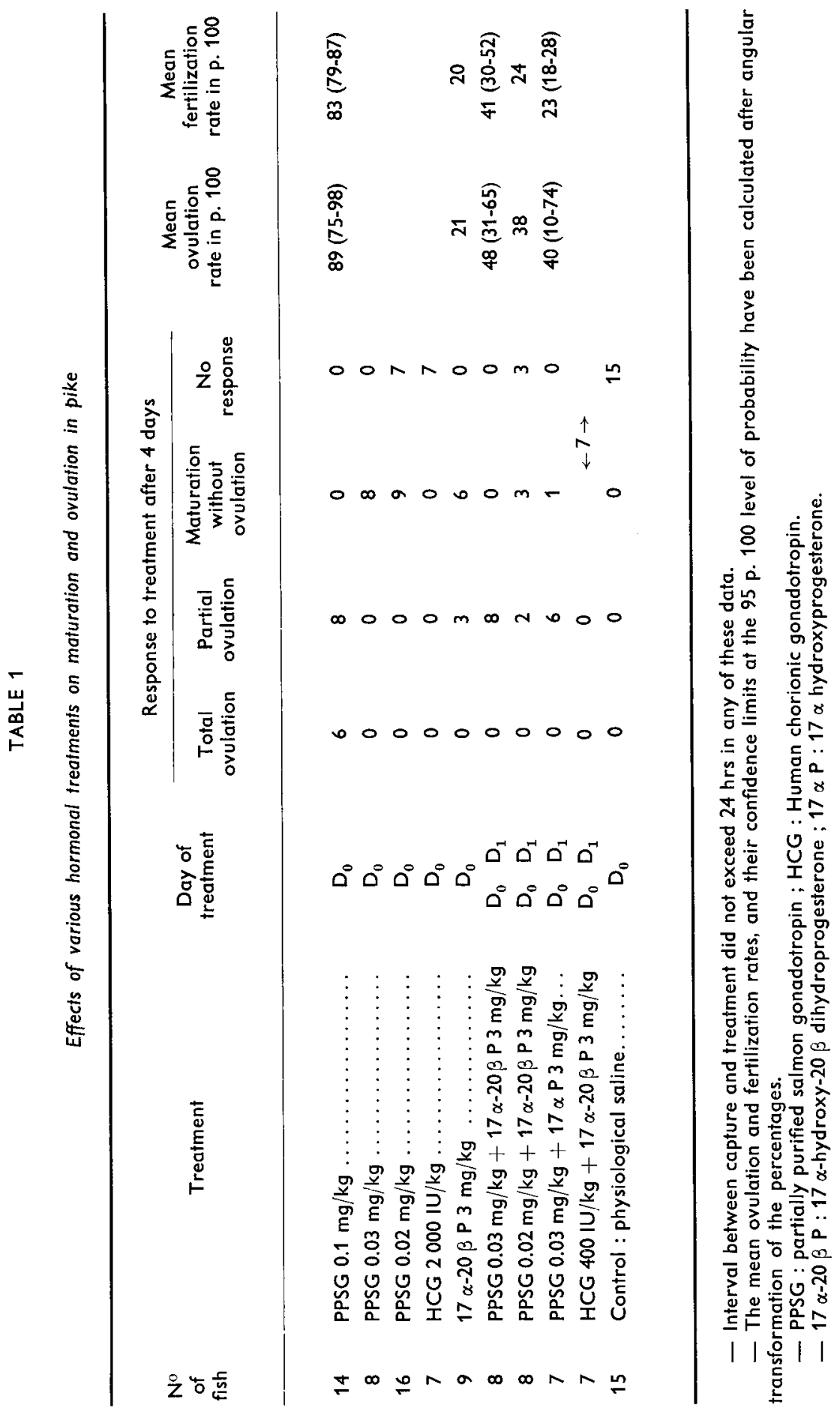


In female treated with HCG as well as in controls there was no change but degeneration.

\section{Fertilization rate (table 1 ).}

The best results (mean fertilization rate : 83 p. 100) were obtained with the highest dose of PPSG $(0.1 \mathrm{mg} / \mathrm{kg})$. With the sequential treatment (PPSG, $0.03 \mathrm{mg} / \mathrm{kg}+17 \alpha-$ $20 \beta$ P, $3 \mathrm{mg} / \mathrm{kg}$ ) the fertilizability of the ovulated oocytes (41 p. 100) was significantly lower $(P<0.001)$. Although $17 \alpha P$ and $17 \alpha-20 \beta P$ associated with PPSG exhibited a similar efficiency on ovulation rates (40 and 48 p. 100) the PPSG-17 $\alpha-20 \beta$ P combination led to significantly higher fertilization rates (41 p. 100 , versus 23 p. 100 with the PPSG-17 $\alpha$ P association).

Effects of various time intervals between capture and treatment on ovulation and fertilization rates (fig. 1).

Mean ovulation rate was 96 p. 100 when treatment was initiated on the very day of capture. It dropped to 40 p. 100 when the females were confined during three days before treatment (the difference is significant at the 1 p. 1000 level of probability). However, the fertility of ovulated oocytes was not affected.
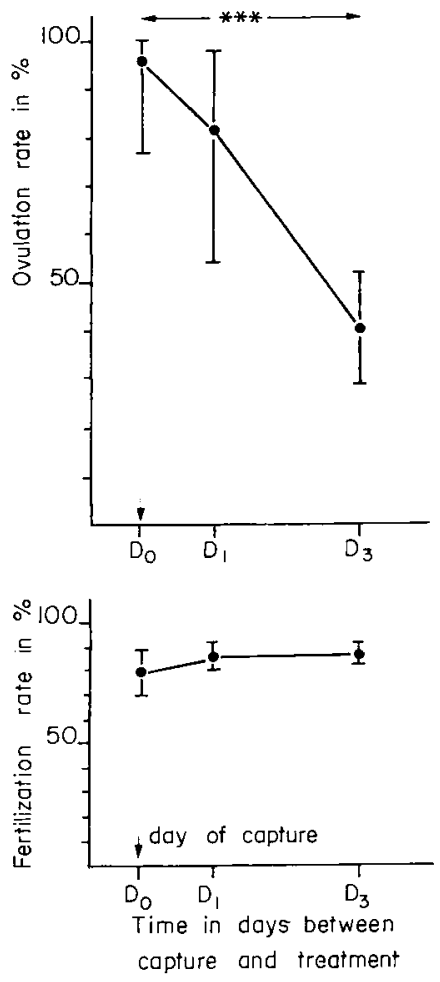

FIG. 1. - Effects of various time intervals between capture and treatment $(0.1 \mathrm{mg}$ PPSG/kg) on ovulation and fertilization rates. Vertical bars show confidence limits at the 95 p. 100 level of probability. *** : highly significant difference $(P<0.001)$. 


\section{Discussion.}

Our results unequivocally indicate the efficiency of an adequate hormonal treatment (a single injection of partially purified salmon gonadotropin administered at the end of vitellogenesis and before completion of the germinal vesicle migration) on in vivo maturation and ovulation in northern pike female. The ova were of good quality, as shown by the high fertilization rates estimated at 40 degree-days (mean : 83 p. 100). Hatching rates were not checked during this investigation, but complementary observations using similarly treated females have shown that embryonic loss does not exceed 15 p. 100 between 40 degree-days and the end of hatching (Bry, unpublished data).

The most striking fact demonstrated here is the considerable loss of responsiveness to hormonal treatment, occurring in all the females after a few days of captivity. A concomitant increase in the proportion of degenerating oocyles was observed from day to day in the control females. Degeneration was characterized by the disappearance of the nucleus and a loss of the homogeneous aspect of the yolk. Handling stress and confinement are certainly responsible for such drastic and irreversible changes. Similar reactions have been noticed in females captured at the stage of oocyte maturation and then transferred under confinement; ovulation does not occur and degeneration takes place (Bry, unpublished observations). In the natural environment, a sudden drop in water temperature may stop normal ovarian evolution, usually before completion of the germinal vesicle migration, and cause widespread atresia (Bry, unpublished observations ; Preudhomme, personal communication). The reproducfive process may also be interrupted after ovulation (no spawning) by stressing tactors such as a cold spell or a drop in water level (June, 1970). Thus, northern pike females appear to be particularly sensitive to various kinds of disturbances in their environment. Regarding the mechanisms involved in the appearance of ovarian atresia in submature captive females, we can only speculate at this moment and evoke a possible lack of gonadotropin or an hormonal unbalance such as hypothetic high levels of some corticosteroids. Our data clearly show that a minimum amount of gonadotropin is absolutely necessary to obtain both complete ovulations and high fertilization rates.

The situation of hormonal receptivity in pike is similar to that in rainbow trout, where $17 \alpha-20 \beta \mathrm{P}$ can induce in vivo oocyte maturation and ovulation only in females treated at the peripheral or subperipheral nucleus stage (Jalabert et al., 1976). If treated at more precocious stages, most females undergo maturation without ovulation. The connection between the time-related physiological events of maturation and ovulation seems to be lacking at this stage but can be restored by a pituitary priming before the steroid injection ; this suggests a pituitary controlled acquisition of a specific mechanism for ovulation (Jalabert et al., 1978).

Symposium sur la Reproduction des Poissons Paimpont, France, 19-21 septembre 1977.

Acknowledgments. - This work was supported by a grant from « Le Conseil Supérieur de la Pêche ». The authors wish to thank Dr. B. Breton for providing the partially purified salmon gonadotropin and Mrs. J. Marcel for secretarial assistance. 
Résumé. L'efficacité d'une préparation d'hormone gonadotrope de saumon partiellement purifiée (PPSG) et de la gonadotropine chorionique (HCG), associées ou non à un progestagène (17 $\alpha$-hydroxy, 20ß-dihydroprogestérone : $17 \alpha-20 \beta$ P ou $17 \alpha$-hydroxyprogestérone : $17 \alpha \mathrm{P}$ ) a été testée chez des femelles de Brochet submatures (stade initial des ovocytes : vésicule germinative non périphérique).

a) Une dose de $0,1 \mathrm{mg} / \mathrm{kg}$ de PPSG a conduit à des taux satisfaisants d'ovulation ( $89 \mathrm{p} .100)$ et de fécondation ( 83 p. 100); une dose minimum de $0,03 \mathrm{mg} P P S G / \mathrm{kg}$ a permis d'induire la maturation sans l'ovulation.

b) La même dose de PPSG $(0.03 \mathrm{mg} / \mathrm{kg})$, suivie à $24 \mathrm{~h}$ d'intervalle par de la $17 \alpha-20 \beta \mathrm{P}$ $(3 \mathrm{mg} / \mathrm{kg})$ ou de la $17 \alpha \mathrm{P}(3 \mathrm{mg} / \mathrm{kg})$ a provoqué des maturations complètes et des ovulations partielles.

La $17 \alpha-20 \beta$ P ( $3 \mathrm{mg} / \mathrm{kg})$, injectée seule, a induit la maturation chez tous les animaux traités et des ovulations partielles ou pas d'ovulation. Dans tous les cas précités $(\S b)$, la fécondabilité a été médiocre ( 20 à 41 p. 100).

c) HCG, seule ou en association avec la $17 \alpha-20 \beta P(3 \mathrm{mg} / \mathrm{kg})$ n'a en aucun cas provoqué d'ovulation. Il est essentiel de débuter le traitement hormonal dès que possible après la capture. Trois jours de captivité avant le traitement ont provoqué une atrésie ovarienne ef une diminution significative des taux d'ovulation.

\section{References}

BILLARD R., 1977. Utilisation d'un système Tris-glycocolle pour tamponner le dilueur d'insémination pour truite. Bull. fr. Pisci., 264, 102-112.

BRETON B., PRUNET P., REINAUD P., 1978. Sexual differences in fish gonadotropins. Ann. Biol. anim. Bioch. Biophys., 18, 759-765.

CHIMITS P., 1947. Note sur le repeuplement artificiel du brochet. Bull. fr. Pisci., 146, 16-24.

CHIMITS P., 1956. Le brochet. Bull. fr. Pisci., 180, 81-96.

DONALDSON E. M., YAMAZAKI F., DYEH. M., PHILLEO W. W., 1972. Preparation of gonadotropin from Salmon (Oncorhynchus tshawytscha) pituitary glands. Gen. comp. Endocrinol., 18, 469-481.

IDLER D. R., BAZAR L. S., HWANG S. J., 1975. Fish gonadotropin(s). II. - Isolation of gonadotropin(s) from chum salmon pituitary glands using affinity chromatography. Endocr. Res. Commun., 2, 215-235.

JALABERT B., BRETON B., 1973. In vitro maturation of pike (Esox lucius) oocytes. Gen. comp. Endocrinol., 22, 391 (Abstr.).

JALABERT B., BRY C., BRETON B., 1972. Maturation et ovulation in vitro des ovocytes de la truite Arc-en-ciel Salmo gairdneri. C. R. Acad. Sci. Paris, Sér. D, 275, 1139-1142.

JALABERT B., BRY C., SZÖLLÖSI D., FOSTIER A., 1973. Ełude comparée de l'action des hormones hypophysaires ef stéroïdes sur la maturation in vitro des ovocytes de la truite et du carassin (Poissons téléostéens). Ann. Biol, anim. Bioch. Biophys., 13, 59-72.

JALABERT B., BRY C., BRETON B., CAMPBELL C., 1976. Action de la $17 \alpha$-hydroxy-20ß-dihydroprogestérone ef de la progestérone sur la maturation ef l'ovulation in vivo et sur le niveau d'hormone gonadotrope plasmatique t-GTH chez la truite Arc-en-ciel. C. R. Acad. Sci. Paris, Sér. D, 283, 1205-1208.

JALABERT B., BRETON B., BRZUSKA E., FOSTIER A., WIENIAWSKI J., 1977. A new tool for induced spawning ; the use of $17 \alpha$-hydroxy-20 $\beta$ dihydroprogesterone to spawn carp at low temperature. Aquaculture, 10, 353-364.

JALABERT B., BRETON B., FOSTIER A., 1978. Precocious induction of maturation and ovulation in rainbow trout (Salmo gairdneri) : problems when using $17 \alpha$-hydroxy-20 $\beta$ dihydroprogesterone. Ann. Biol. anim. Bioch. Biophys., 18, 977-984.

JUNE F. C., 1970. Atresia and year-class abundance of northern pike, Esox lucius in two Missouri river impoundments. J. Fish. Res. Bd. Conado, 27, 587-591.

PORTAL J., 1947. Observations sur la pisciculture artificielle du brochet. Bull. fr. Pisci., 147, 61-70.

SHEHADEH Z. H., 1975. Induced breeding techniques. A review of progress and problems. In : Workshop on controlled reproduction of cultivated fishes. EIFAC tech. Pap., 25, 72-89.

SORENSON L., BUSS K., BRADFORD A. D., 1966. The artificial propagation of esocid fishes in Pennsylvania. Prog. Fish. Cult., 28, 133-141. 